\title{
Internal Control Disclosure and Corporate Governance: Empirical Research from Chinese Listed Companies*
}

\author{
Jianfei Leng, Yiran Ding \\ School of Business, Hohai University, Nanjing, China \\ E-mail: ljf200209@gmail.com,graceding1002@126.com \\ Received September 16, 2011; revised October 14, 2011; accepted November 5, 2011
}

\begin{abstract}
The aim of this paper is to research the influence of corporate governance structure on internal control disclosure in a sample of 1309 Chinese listed nonfinancial companies in 2010. We discover that internal control disclosure is positively related to directors' remuneration, two part-time posts of chairman and general manager, directors' education level and supervisors' education level, and it negatively related to the proportion of state ownership. Internal control disclosure is not significantly related to the degree of ownership concentration, board size, the proportion of independent directors and the size of board of supervisors.
\end{abstract}

Keywords: Listed Companies, Corporate Governance, Internal Control, Information Disclosure

\section{Introduction}

Currently, many well-known companies have been revealed financial fraud scandals such as Enron, WorldCom, Xerox, Guangxia and China Aviation Oil. One of the important reasons of financial fraud is the failure of internal control and the lack of related information disclosure. Effective internal control system can ensure the truthfulness and reliability of financial information. Information disclosure can contribute to the constant improvement of internal control, offering data for decision-making to information users. The establishment and effective implementation of internal control system can assure the corporate continuing operating and developing healthily. The quality of internal control disclosure reflects the situation of the system, which is vital to regulators and investors. Information disclosure quality of a listed company is subjected to its corporate governance. Different corporate governance structures will bring different governance efficiency. Consequently, this paper is to study the influence of corporate governance structure on internal control disclosure.

In this paper we test whether quality of internal control disclosure are associated with corporate governance characteristics in the sample of 1309 Chinese nonfinancial listed companies on Shenzhen Stock Exchange and

*Fund: operation expenses for Hohai University's basic scientific research of central authorities "Research of internal control Information Disclosure in Chinese listed companies” (2009B23514).
Shanghai Stock Exchange for the financial year of 2010. Descriptive statistics presents the characteristics of variables. There are significant differences between the quailties of internal control disclosure of Chinese listed companies. The degree of ownership concentration varies considerably and is generally high. The proportion of state ownership is to some extent lower than before. There are big differences in board sizes; however, the average size is moderate. The remuneration is quite different and directors generally highly educated. The proportion of independent directors generally meets the requirement of no less than $1 / 3$ of board members. The phenomenon of two part-time posts of chairman and general manager is not widespread. The sizes and the education levels of board of supervisors also vary. Size, profitability and listed age of each company are quite different. $64 \%$ of sample companies listed on Shanghai Stock Exchange and 36\% listed on Shenzhen Stock Exchange.

Correlation analysis tests collinearity between variables. Collinearity doesn't exist if the correlation coefficient is not greater than 0.8 , according to the study of Hossain, Perera and Rahman [1]. Analysis shows there is some correlation between variables, but the largest correlation coefficient is 0.462 (between directors' education level and supervisors' education level), which is less than 0.8 . Thus variables are unlikely collinear. To further illustrate the problem, we also test tolerance and variance inflation factor. The minimum of tolerance is 0.657 (the 
size of board of supervisors), more than 0.1, and the maximum of variance inflation factor is 1.522 , less than 10 , which means no collinearity between variables according to laws of mathematical statistics.

The result of linear regression suggests that directors' education level, supervisors' education level, size, listed age and stock exchange significantly influence on the quality of internal control disclosure at the 0.001 confidence level. Internal control disclosure is positively related to directors' education level, supervisors' education level and size and negatively related to listed age and stock exchange, which verifies hypothesis 6 and hypothesis 9. The proportion of state ownership, two parttime posts of chairman and general manager, directors' remuneration and profitability significantly influence on internal control disclosure at the 0.1 confidence level, which verifies hypothesis 2 and hypothesis 5 . However, internal control disclosure is not significantly related to the degree of ownership concentration, board size, the proportion of independent directors and the size of board of supervisors. Other hypotheses are not verified.

The remainder of the paper is organized as follow: Section 2 discusses prior research on internal control disclosure. Section 3 describes the method of the study. Section 4 presents empirical results. Section 5 draws some conclusions.

\section{Prior Research on Internal Control Disclosure}

In 1978, Cohen Commission (the Commission on Auditors' Responsibilities) required that the management should assess internal control system. In 1992, COSO (The Committee of Sponsoring Organizations of The National Commission of Fraudulent Financial Reporting) issued Internal Control-Integrated Framework, providing a more comprehensive framework of internal control. Internal control disclosure changed from voluntary disclosure to mandatory one, after Sarbanes-Oxley Act was passed and implemented in July 2002.

In 2006, Shanghai Stock Exchange (referred to as SSE) and Shenzhen Stock Exchange (referred to as SZSE) issued Internal Control Guidelines of Listed Companies in Shanghai Stock Exchange and Internal Control Guidelines of Listed Companies in Shenzhen Stock Exchange, which are legal norms for Chinese listed companies to disclose internal control from voluntarily to mandatorily.

\subsection{Quality of Internal Control Disclosure}

Raghunandan and Rama [2] investigated the annual reports 1993 of top 100 listed companies in Fortune, and found that $80 \%$ of the companies disclosed information of internal control without a uniform form. McMullen, Raghunandan and Rama [3] discovered that only 742 companies, accounting $33.41 \%$ of 2221 companies, disclosed information of internal control management and only 55 companies made a statement on the effectiveness of internal control, by studying annual reports 1993 of listed companies. Willis and Lightle [4] also found a decline in the number of companies disclosing internal control and big differences between the qualities of disclosure by analyzing the reports of top 100 companies. They stated that the disclosure of internal control will contribute to firm's value.

Qiuming Liu [5] and Minghui Li, Hai He and Xikui Ma [6] examined the quality of internal control disclosure of Chinese listed companies in 2001. They found that most companies' information disclosure merely focused on formality without uniform content and format. Liming Zhang, Hua Qian and Minyi Li [7] tested ST listed companies between 2001 and 2002. The result showed that there were loopholes in disclosure though there were more firms disclosing internal control reports, and auditors are less concerning about internal control information of commissioned companies. Hongxing Fang and He Sun [8] and Youhong Yang and Wei Wang [9] investigated the disclosure reports about internal control of listed nonfinancial companies on SSE in 2006. They found that most companies didn't follow the requirements of Internal Control Guidelines. Junmei Pan [10], analyzing the annual reports of 15 listed companies on SSE and 29 listed companies on SZSE between 2005 and 2007, discovered many problems in internal control disclosure, such as standard and format being not uniform, content being formality and the lack of motivation of voluntary disclosure and assessment criteria. Significant differences were found between banks' disclosure by examining the quality of internal control disclosure of Chinese listed banks based on the case of Minsheng Bank (Xu Qu, Ming Li, Dan Yang and Jianming Ye [11]).

\subsection{Influential Factors of Internal Control Disclosure}

Deumes [12] tested 149 listed companies of Dutch stock market, discovering that internal control disclosure is in connection with managerial shareholding level, the degree of ownership concentration, size and the reputation of commissioned audit firm. McMullen, Raghunandan and Rama [3] concluded that internal control disclosure is negatively related to ill financial reports, by examining the annual reports of 4154 companies from 1989 to 1993. Ge and McVay [13] empirically researched 261 listed companies, finding that the defects of internal control is 
positively related to the complexity of the business and negatively related to size and profitability. Jifu Cai [14] empirically researched Chinese A-share listed companies in 2003, indicating that the quality of disclosure is positively related to profitability, financial situation and the quality of financial report. Bronson et al. [15] suggested that the quality of disclosure is positively related to the times of audit committee meetings and net profit growth rate and negatively related to sales growth rate.

Hongxing Fang and He Sun [8] illustrated internal control disclosure is in connection with stock exchange, size, type of auditors' opinion in a sample of nonfinancial companies listed on SSE in 2006. Xinhong Li [16] verified that the quality of disclosure is associated with stock market, region, size, the proportion of independent directors, profitability, the reputation of underwriters, whether being penalized and the type of auditors' opinion, by analyzing listed companies on SSE in 2006. Ashbaugh-Skaife, Collins and Kinney [17] and Doyle, Ge and McVay [18] investigated the connection between corporate characteristics and the disclosure of internal control defects, discovering the latter is significantly related to the complexity of organization, risk control factors, the input into internal control and external stimulus factors.

\subsection{Influence of Corporate Governance on Internal Control Disclosure}

Jensen [19] studied the failure of internal control mechanisms, thought the effect of internal control is negatively related to board size and board governance efficiency. Simon Ho and Kar Shun Wong [20] observed that voluntary disclosure of internal control is positively related to the existence of audit committee and negatively related to the proportion of family members in the firm. Eng and Mak [21] examined the influence of ownership structure and board structure on voluntary disclosure, the result showing that internal control disclosure is positively related to the perfection degree of corporate governance, in a sample of 158 listed companies in Singapore.

Weizhen Xu [22] studied the Accountability Theory and the relationship between corporate governance and internal control, analyzing the necessity of internal control disclosure to corporate governance. Zhijun Ma [23] also thought the quality of internal control disclosure is subjected to the efficiency of corporate governance and proposed suggestion and measures from the perspectives of the improvement of ownership structure and the establishment of internal control mechanism. Shaoqing Song [24] investigated the influence of corporate governance on internal control disclosure, discovering that the qual- ity of disclosure is significant related to audit committee, the degree of legal protection to investors, the perfection degree of stock exchange governance and external governance mechanism. Shuguang Zhou and Lirong Chen [25] examined 1557 nonfinancial listed companies on SZSE and SSE in 2008, the result showing that corporate governance is one of the vital factors which influence the quality of disclosure. Internal control disclosure is positively related to board size, the proportion of independent directors, audit committee and whether controlling shareholder being state-owned and negatively related to two part-time posts of chairman and general manager.

\subsection{Comments on Prior Research}

We can summarize that foreign scholars study the issue of internal control disclosure very early and their research are based on rigorous theoretical and empirical test from various perspectives. They have got remarkable achievements, which give more help to a large of Chinese research. However, every country varies in the environment of economy, politics and society, which leads to the result that many foreign conclusions cannot be verified in Chinese research. When analyzing the influence of corporate governance, our scholars basically learn from foreigners, choosing variables from aspects of ownership structure and board characteristics and ignoreing the effect of board of supervisors which means that there are deficiencies in picking up variables.

Therefore, we investigate the influence of corporate governance on the quality of internal control disclosure in depth, from the perspectives of ownership structure, board characteristics and the characteristics of board of supervisors, providing practical suggestion and measures to disclosure improvement.

\section{Method}

\subsection{Hypotheses}

\subsubsection{Ownership}

The degree of ownership concentration affects on the quality of internal control disclosure because of the restraints of the decentralization of shares on shareholders, which makes them require high quality of disclosure. The higher the degree of ownership concentration, the weaker the restraint effect, which makes majority shareholders harm the interests of minority shareholders. Majority shareholders may conceal or even falsely disclose some important but unfavorable information, using their advantageous controlling position or conspiring with the management, in order to protect their own interests.

Hypothesis 1: internal control disclosure is negatively 
related to the degree of ownership concentration.

Many Chinese listed companies come from joint-stock reform of state-owned enterprises. As agents of state ownership, organizations of state-owned assets supervision and administration cannot play an effective role in corporate governance and effective supervision and incentives to the management, which leads to insider control. The management may have the opportunity to make a use of government's weak control over property and conceal vital information to protect its own interests. High proportion of state ownership means it is hard to restrain the management and brings low quality of internal control disclosure.

Hypothesis 2: internal control disclosure is negatively related to the proportion of state ownership.

\subsubsection{Board}

As the core of corporate governance, board of directors is responsible for the establishment and implementation of internal control system, ensuring the truthfulness and reliability of information disclosure. Board size, to some extent, reflects the ability of directors to participate in major business decision-making and monitor the management for the reason that bigger board contains more members with expertise and experience from various professional fields. Board size could improve the quality of disclosure.

Hypothesis 3: internal control disclosure is positively related to board size.

As the internal supervision organization, the board of supervisors is entitled to monitor the board and the management, supervising the establishment and implementation of internal control system. Supervisors own not the right of decision but the right of supervision. The effect of supervisors is often neglected. The size of board of supervisors can show the influence of supervisors and affect internal control disclosure.

Hypothesis 4: internal control disclosure is positively related to the size of board of supervisors.

\subsubsection{Directors and Supervisors}

Remuneration is a very effective incentive measure for board directors to monitor and restrain the management and join major decision-making, which means high remuneration will encourage directors to establish internal control system and require high quality of disclosure.

Hypothesis 5: internal control disclosure is positively related to directors' remuneration.

Directors' education level, in some degree, shows directors' capability of corporate governance. Generally speaking, higher education level means more professsional knowledge and skills. Thus directors with high education level are more adequate to fulfill their respon- sibilities that doing decision-making, monitoring the management, internal controlling and requiring high quality of information disclosure.

Hypothesis 6: internal control disclosure is positively related to directors' education level.

Independent directors are expected to monitor and challenge the performance of the executive directors and the management, and to take a determined stand in the interests of the firm and its stakeholders. They're usually experts of various fields such as economy, laws, accounting and tax. Independent directors are responsible for helping improve the quality of disclosure and increase the transparency of information.

Hypothesis 7: internal control disclosure is positively related to the proportion of independent directors.

A chairman and a general manager is the relationship between the supervisor and the supervised. The separation of the two positions improves the independence of the board and strengthens the supervision over the management, which contributes to increase the transparency of information. However, there is a phenomenon that a chairman who is also the general manager in some firms. According agency theory, two part-time posts of chairman and general manager may reduce the board's independence and weaken the supervision over the management; as a result, the firm will conceal or falsely disclose disadvantageous information and lower the quality of disclosure.

Hypothesis 8: internal control disclosure is negatively related to two part-time posts of chairman and general manager.

Supervisors' education level presents supervisors' capability of monitoring the board and the manager. Higher education level means more adequate to supervision, more effective to monitor implementation of internal control system and higher requirement to information disclosure.

Hypothesis 9: internal control disclosure is positively related to supervisors' education level.

\subsection{Sample}

Our sample consists of all nonfinancial listed companies on SZSE and SSE in the financial year of 2010. We obtain a total of 1309 companies, 465 listed on SZSE and 844 listed on SSE, which meet our selection criteria. Financial companies are excluded from the sample for the reason that they have special rules of internal control disclosure, which makes they're uncomparable with nonfinancial companies.

The annual reports and data used in this paper are coming from RESST financial database (www.resset.cn), CNINFO website (www.cninfo.com.cn), website of SZSE 
(www.szse.cn) and website of SSE (www.sse.com.cn). We use SPSS 16.0 to analyze data.

\subsection{Variables}

\subsubsection{Dependent Variable}

The quality of internal control disclosure is an abstract indicator that can not be directly measured, so we need to design evaluation criteria to measure it. There are two methods that foreign researchers adopt. One is the rating of authority, such as Standard \& Poor's rating and CIFAR Index. The other is content analysis that information is quantified based on its content. It is a research method to describe disclosure information objectively and quantitatively. Guoping Wu, Qin Wang and Shan Jia [26], Shaoqing Song and YaoZhang [27], Lirong Chen and Shuguang Zhou [28] and Yufeng Yang, Huoxin Wang and Qiong Cao [29] all set criteria to measure the quality of internal control disclosure.

We use content analysis and design an evaluation criterion to calculate internal control disclosure index (referred to as ICDI) to measure disclosure quality on the basis of prior research: Basic Norms of Internal Control, Guidelines of Internal Control for Shenzhen Stock Exchange Listed Companies and Guidelines of Internal Control for Shanghai Stock Exchange Listed Companies. We define ICDI according to the equation: ICDI = ICD/ MICD

Where, ICDI means internal control disclosure index, ICD means scores of every item of internal control information disclosed in annual reports and MICD means the total score of the maximum possible disclosure items $(\mathrm{MICD}=8)$. Table 1 is the evaluation criterion of internal control disclosure.

\subsubsection{Independent Variables}

We select 9 independent variables on the basis of the hypotheses proposed above.
1) The degree of ownership concentration (DOC): We use the proportion of the largest shareholder to measure the degree of ownership concentration. DOC = the number of the largest shareholder's shares/the total number of shares.

2) The proportion of state ownership (PSO): PSO = the number of state-owned shares/the total number of shares.

3) Board size (BS): The total number of board directors.

4) Directors' remuneration (DR): We choose the Napierian logarithm of total remuneration of the top three directors to weight DR.

5) Directors' education level (DEL): DEL is the average education level of directors. DEL $=$ the sum of directors' education level/the number of directors. Education level is quantified as below. Without a bachelor's degree $=1$, with a bachelor's degree $=2$, with a master's degree $=3$ and with a doctorate $=4$.

6) The proportion of independent directors (PID): The number of independent directors/the total number of directors.

7) Two part-time posts of chairman and general manager (PCGM): If a chairman is also the general manager, PCGM $=1$, otherwise, PCGM $=0$.

8) The size of board of supervisors (SBS): The total number of supervisors.

9) Supervisors' education level (SEL): SEL is the average education level of supervisors. SEL $=$ the sum of supervisors' education level/the number of supervisors. Education level is quantified as above.

\subsubsection{Control Variables}

They have other variables impact on the quality of internal control disclosure except for corporate governance. Consequently, we adopt some control variables.

1) Size: Large companies, with great strength, are more likely to put resources into internal control development, which leads to more effective control and higher

Table 1. Evaluation sheet.

\begin{tabular}{|c|c|c|}
\hline Items & Content & Scores \\
\hline Internal Environment & $\begin{array}{l}\text { Governance corporate structure, human resources politics, corporate culture, } \\
\text { management concepts of the management, etc. }\end{array}$ & Disclosing $=1$, Otherwise $=0$ \\
\hline Risk Evaluation & Identification of internal and external risks, risk analysis, risk response, etc. & Disclosing $=1$, Otherwise $=0$ \\
\hline Control Activities & Internal control activities based on risk evaluation & Disclosing $=1$, Otherwise $=0$ \\
\hline Information \& Communication & The establishment of information and communication system & Disclosing $=1$, Otherwise $=0$ \\
\hline Internal Supervision & Internal supervision from internal audit department or other department & Disclosing $=1$, Otherwise $=0$ \\
\hline Internal Control Defects & The defects or abnormal items in internal control and the improvement measures & Disclosing $=1$, Otherwise $=0$ \\
\hline Internal Assessment & Assessment from board of directors or board of supervisors & Disclosing $=1$, Otherwise $=0$ \\
\hline External Assessment & Assessment from audit agency & Disclosing $=1$, Otherwise $=0$ \\
\hline
\end{tabular}


quality of disclosure. We use the Napierian logarithm of total assets to measure size.

2) Profitability (EPS): Companies of strong profitability have more financial resources to establish and implement internal control system and are more likely to disclose information. We select earning per share (EPS) to weight profitability. EPS = net profit/the total number of shares.

3) Listed age (LA): According to the research of DIB Company in 2008, the quality of internal control in later listed companies is better than it in earlier listed companies. Listed age in this paper means the number of years from the very year of being public company to 2010 .

4) Stock exchange (SE): We take stock exchange into consideration for the reason that there are some difference in rules between SZSE and SSE. If a company is listed in $\mathrm{SSE}, \mathrm{SE}=1$, otherwise, $\mathrm{SE}=0$.

\subsection{Model}

We investigate the correlation between corporate governance characteristics and the quality of internal control disclosure, using ICDI as dependent variable, corporate governance indicators as independent variables and some control variables mentioned above. Our basic model is the following linear regression.

$$
\begin{aligned}
\mathrm{ICDI}= & \alpha+\beta_{1} \cdot \mathrm{DOC}+\beta_{2} \cdot \mathrm{PSO}+\beta_{3} \cdot \mathrm{BS} \\
& +\beta_{4} \cdot \mathrm{DR}+\beta_{5} \cdot \mathrm{DEL}+\beta_{6} \cdot \mathrm{PID} \\
& +\beta_{7} \cdot \mathrm{PCGM}+\beta_{8} \cdot \mathrm{SBS}+\beta_{9} \cdot \mathrm{SEL} \\
& +\beta_{10} \cdot \mathrm{SIZE}+\beta_{11} \cdot \mathrm{EPS}+\beta_{12} \cdot \mathrm{LA} \\
& +\beta_{13} \cdot \mathrm{SE}+\varepsilon
\end{aligned}
$$

where, $\alpha$ is a constant term, $\beta_{i}$ are coefficients of independent variables and control variables $(i=1,2, \cdots, 13)$ and $\varepsilon$ is random error.

\section{Empirical Results}

\subsection{Descriptive Statistics}

Table 2 presents descriptive data for the sample. The minimum of ICDI is 0.125 , the maximum is 1 , the mean is 0.6367 and the standard deviation is 0.2312 , which means Chinese listed companies vary a lot and the average level is not very high.

1) The minimum of DOC is $3.64 \%$ and the maximum is $99 \%$, which suggests that there are considerable differences in the degree of ownership concentration. The mean is $36.45 \%$, which shows high average level and a dominance phenomenon. 2) The maximum of PSO is $100 \%$ while the minimum is 0 , which also reflects great differences and the mean of $14.03 \%$ means that the pro-
Table 2. Descriptive statistics.

\begin{tabular}{ccccc}
\hline & Minimum & Maximum & Mean & Std. Deviation \\
\hline ICDI & 0.1250 & 1.000 & 0.6367 & 0.2312 \\
DOC & 0.0364 & 0.9900 & 0.3645 & 0.1658 \\
PSO & 0.0000 & 1.0000 & 0.1403 & 0.2193 \\
BS & 5 & 34 & 12.7500 & 3.9540 \\
DR & 9.0000 & 16.4145 & 13.4799 & 0.9351 \\
DEL & 1.2000 & 3.7500 & 2.4340 & 0.7873 \\
PID & 0.0667 & 0.8000 & 0.3367 & 0.0856 \\
PCGM & 0 & 1 & 0.1600 & 0.3640 \\
SBS & 1 & 19 & 5.4900 & 2.3320 \\
SEL & 1.0000 & 3.6000 & 2.1050 & 0.6794 \\
SIZE & 11.3500 & 28.0000 & 21.7821 & 1.4670 \\
EPS & -4.2000 & 4.6000 & 0.2300 & 0.5151 \\
LA & 0 & 20 & 11.6900 & 3.9500 \\
SE & 0 & 1 & 0.6400 & 0.4790 \\
Valid N & 1309 & & & \\
(listwise) & & & & \\
\hline
\end{tabular}

portion of state ownership is lower than before. 3) The general board size complies with organizational theory though the size of board differs (the minimum is 5 , the maximum is 34 and the mean is 12.75). 4) Directors' remuneration is quite different between listed companies because the maximum of DR is 16.4145 , whereas the minimum is 9. 5) The average level of directors' education is above bachelor's degree and the highest is doctorate degree, which means directors are generally highly educated (the mean of DEL is 2.434 and the maximum is 3.75). 6) The mean of PID is $33.67 \%$ which means most companies meet the requirement that the proportion of independent directors shouldn't be lower than 1/3 of China Securities Regulatory Commission. 7) The phenomenon of two part-time posts of chairman and general manager is not widespread (the ratio is 16\%). 8) There are great differences in the size of board of supervisors that the minimum of SBS is 1 and the maximum is 19.9) The average level of supervisors' education is also different (the minimum of SEL is 1, the maximum is 3.6 and the mean is 2.105).

\subsection{Correlation Analysis}

We use Pearson correlation coefficient to test collinearity between variables. Hossain, Perera and Rahman [1] 
thought that collinearity doesn't exist if the correlation coefficient is not greater than 0.8 .

Table 3 shows correlation coefficients between variables. ICDI is significantly related to DOC, DR, DEL, SEL, SIZE, EPS and SE at the 0.01 level and correlation coefficients are $-0.098,0.182,0.720,0.463,0.254,0.166$ and -0.294 . ICDI is significantly related to LA with a coefficient of -0.063 at the 0.05 level. However, ICDI is not significantly related to PSO, BS, PID, PCGM and SBS. There is some correlation between variables, whereas the largest correlation coefficient is 0.462 (between DEL and SEL), which is less than 0.8. Thus variables are unlikely collinear.

We also test tolerance and variance inflation factor to further illustrate the problem. Table 4 illustrates that the minimum of tolerance is 0.657 (SBS), larger than 0.1 , and the maximum of variance inflation factor is 1.522 , less than 10 , which means no collinearity between variables, according to laws of mathematical statistics.

\subsection{Linear Regression Results}

Table 5 presents the linear regression results of our model.

1) The goodness of fit (adjusted R square) is 0.582, which indicates our model is satisfactory.

2) $\mathrm{F}$ value of the regression model is 141.331 and the statistical significance (sig.) is 0.000 , lower than 0.001 , which means the model is statistically significant.

3) Regression results show that DEL, SEL, SIZE, LA and SE quite significantly influence on ICDI at the 0.001 confidence level. PSO, DR, PCGM and EPS significantly influence on ICDI at the 0.1 confidence level. However, ICDI is not significantly related to DOC, BS, PID and SBS.

4) The quality of internal control disclosure is negatively associated to the proportion of state-owned shares, which verifies hypothesis 2 . And it is positively related to directors' remuneration and the education level of both directors and supervisors, which verifies hypothesis

Table 3. Correlation between vectors of values (Pearson).

\begin{tabular}{|c|c|c|c|c|c|c|c|c|c|c|c|c|c|c|}
\hline & ICDI & DOC & PSO & BS & DR & DEL & PID & PCGM & SBS & SEL & SIZE & EPS & LA & SE \\
\hline ICDI & 1 & $-0.098 * *$ & -0.052 & 0.048 & $0.182^{* *}$ & $0.720 * *$ & 0.031 & 0.012 & 0.028 & $0.463^{* *}$ & $0.254 * *$ & $0.166^{* *}$ & $-0.063 *$ & $-0.294 * *$ \\
\hline DOC & & 1 & $0.439 * *$ & $-0.072^{* *}$ & 0.041 & $0.129 * *$ & $0.070 *$ & $-0.155^{* *}$ & 0.014 & $0.163^{* *}$ & $0.373 * *$ & $0.160 * *$ & $-0.273 * *$ & $0.130 * *$ \\
\hline PSO & & & 1 & 0.042 & -0.005 & $0.094 * *$ & $0.082 * *$ & $-0.066^{*}$ & 0.039 & $0.099 * *$ & $0.245 * *$ & 0.048 & $-0.208^{* *}$ & 0.017 \\
\hline DR & & & & & 1 & $0.163^{* *}$ & 0.053 & -0.004 & -0.009 & $0.104^{* *}$ & $0.362 * *$ & $0.353^{* *}$ & $-0.089 * *$ & $0.105^{* *}$ \\
\hline DEL & & & & & & 1 & 0.039 & -0.036 & 0.042 & $0.462 * *$ & $0.232 * *$ & $0.122 * *$ & -0.045 & $-0.209 * *$ \\
\hline PID & & & & & & & 1 & -0.008 & $-0.149 * *$ & $0.060 *$ & $0.133^{* *}$ & -0.002 & $-0.202^{* *}$ & $0.068^{*}$ \\
\hline SBS & & & & & & & & & 1 & $0.075^{* *}$ & $0.066^{*}$ & -0.004 & $0.071^{*}$ & -0.016 \\
\hline SEL & & & & & & & & & & 1 & $0.232^{* *}$ & $0.087 * *$ & -0.036 & $-0.077^{* *}$ \\
\hline SIZE & & & & & & & & & & & 1 & $0.329 * *$ & $-0.216^{* *}$ & $=0.145 * *$ \\
\hline EPS & & & & & & & & & & & & 1 & $-0.099 * *$ & 0.007 \\
\hline LA & & & & & & & & & & & & & 1 & $-0.322 * *$ \\
\hline SE & & & & & & & & & & & & & & 1 \\
\hline
\end{tabular}

*Correlation is significant at the 0.05 level (2-tailed); **Correlation is significant at the 0.01 level (2-tailed).

Table 4. Collinearity statistics.

\begin{tabular}{|c|c|c|c|c|c|c|c|c|c|c|c|c|c|}
\hline & DOC & PSO & BS & DR & DEL & PID & PCGM & SBS & SEL & SIZE & EPS & LA & $\mathrm{SE}$ \\
\hline Tolerance & 0.681 & 0.773 & 0.741 & 0.776 & 0.718 & 0.875 & 0.956 & 0.797 & 0.759 & 0.657 & 0.814 & 0.788 & 0.801 \\
\hline VIF & 1.469 & 1.293 & 1.349 & 1.288 & 1.392 & 1.143 & 1.046 & 1.254 & 1.318 & 1.522 & 1.228 & 1.268 & 1.248 \\
\hline
\end{tabular}


Table 5. Regression results.

\begin{tabular}{|c|c|c|c|c|c|}
\hline & \multicolumn{2}{|c|}{$\begin{array}{l}\text { Unstandardized } \\
\text { Coefficients }\end{array}$} & \multicolumn{3}{|c|}{ Standardized Coefficients } \\
\hline & B & Std. Error & Beta & $\mathrm{t}$ & Sig. \\
\hline (Constant) & -0.187 & 0.086 & & -2.169 & 0.030 \\
\hline DOC & -0.019 & 0.030 & -0.014 & -0.637 & 0.524 \\
\hline PSO & -0.050 & 0.021 & -0.047 & -2.331 & 0.020 \\
\hline BS & 0.001 & 0.001 & 0.006 & 0.268 & 0.789 \\
\hline DR & 0.010 & 0.005 & 0.040 & 1.978 & 0.048 \\
\hline DEL & 0.169 & 0.006 & 0.577 & 27.360 & 0.000 \\
\hline PID & 0.039 & 0.052 & 0.014 & 0.751 & 0.453 \\
\hline PCGM & 0.021 & 0.012 & 0.034 & 1.848 & 0.065 \\
\hline SBS & 0.001 & 0.002 & 0.011 & 0.538 & 0.591 \\
\hline SEL & 0.055 & 0.007 & 0.162 & 7.888 & 0.000 \\
\hline SIZE & 0.014 & 0.003 & 0.089 & 4.032 & 0.000 \\
\hline EPS & 0.016 & 0.009 & 0.036 & 1.818 & 0.069 \\
\hline LA & -0.005 & 0.001 & -0.088 & -4.349 & 0.000 \\
\hline SE & -0.096 & 0.010 & -0.199 & -9.966 & 0.000 \\
\hline R Square & 0.587 & & & & \\
\hline $\begin{array}{l}\text { Adjusted R } \\
\text { Square }\end{array}$ & 0.582 & & & & \\
\hline F & 141.331 & & & & \\
\hline Sig & 0.000 & & & & \\
\hline
\end{tabular}

5 , hypothesis 6 and hypothesis 9 . Two part-time posts of chairman and general manager have a positive effect on internal control disclosure, which is opposite to hypothesis 8 . The reason may be that a chairman who is also the general manager is more likely to concern the firm's development and require better internal control system, which makes high quality of internal control implementtation and information disclosure.

\section{Conclusions}

1) This paper tests the influence of corporate governance characteristics on internal control disclosure, in a sample of 1309 Chinese listed nonfinancial companies in 2010. The quality of internal control disclosure varies wildly. The minimum of internal control disclosure index is 0.125 , the maximum is 1 and the mean is 0.6367 . One main reason is that every company's level of internal control differs a lot. The other main reason is the lack of rules and regulations of specific content and uniform format on internal control disclosure, which leads the casualness of disclosure.

2) As agents of state ownership, organizations of stateowned assets supervision and administration can't effecttively affect on corporate governance and supervision and incentives over the management, which leads to insider control. The management may conceal or falsely disclose significant information to protect its own interests. Thus the proportion of state-owned shares should be maintained in appropriate range and the organizations should take their responsibility for supervision and administration of state-owned assets.

3) High remuneration encourages board directors to monitor the manager and join major decision-making, which contributes to the establishment of internal control system and the disclosure of information. Companies should remunerate directors reasonably according to their circumstances.

4) Education level reflects directors' and supervisors' capability of corporate governance, so these high educated own more professional knowledge and skills tofulfill their responsibilities, requiring better internal control and information disclosure. Consequently, education level, as a vital factor, should be taken into consideration of the selection of directors and supervisors.

On the ground of our research, we come up with some suggestion as below. Chinese regulatory organizations should develop rules and regulations on the content and format of internal control disclosure to improve the unity, operability and comparability of disclosure. Furthermore, Chinese listed companies should improve their corporate governance and internal control system for the healthy and development of companies.

\section{References}

[1] M. Hossain, M. Perera and A. R. Rahman, "Voluntary Disclosure in the Annual Reports of New Zealand Companies," Journal of International Financial Management and Accounting, Vol. 6, No. 1, 1995, pp. 69-87. doi:10.1111/j.1467-646X.1995.tb00050.x

[2] K. Raghunandan and D. V. Rama, "Management Reports after COSO,” Internal Auditor, Vol. 8, 1994, pp. 54-49.

[3] D. A. McMullen, K. Raghunandan and D. V. Rama, "Internal Control Reports and Financial Reporting Problem," Accounting Horizons, Vol. 10, No. 12, 1996, pp. 67-75.

[4] D. M. Willis and S. S. Lightle, "Management Reports on Internal Control,” Journal of Accountancy, Vol. 10, 2000, pp. 57-64.

[5] Q. M. Liu, “The Problems and Improvements of Internal Control Disclosure of Chinese Listed Companies," Securities Market Herald, Vol. 6, 2002, pp. 38-43.

[6] M. H. Li, H. He and X. K. Ma, "Analysis of Internal Control Disclosure of Chinese Listed Companies,” $\mathrm{Au}$ diting Research, Vol. 1, 2003, pp. 11-13. 
[7] L. M. Zhang, H. Qian and M. Y. Li, “The Situation and Improvement of Internal Control Disclosure: The Data and Analysis of Chinese ST Listed Companies,” Auditing Research, Vol. 5, 2003, pp. 21-24.

[8] H. X. Fang and H. Sun, "Internal Control Disclosure under the Rules of Mandatory Disclosure: Empirical Research on 2006 Annual Reports of Companies Listed on Shanghai Stock Exchange," Research on Financial and Economic Issues, Vol. 12, 2007, pp. 67-73.

[9] Y. H. Yang and W. Wang, "Research on Internal Control Disclosure of Companies Listed on Shanghai Stock Exchange in 2006," Accounting Research, Vol. 3, 2008, pp. 40-49.

[10] J. M. Pan, "Issues of Internal Control Disclosure of Chinese Listed Companies,” Friends of Accounting, Vol. 2, 2009, pp. 98-101.

[11] X. Qu, M. Li, D. Yang and J. M. Ye, "Research on the Substantial Vulnerability Disclosure of Internal Control of Listed Banks: Based on the Case Study of Minsheng Bank,” Accounting Research, Vol. 4, 2009, pp. 38-46.

[12] R. Deumes, "Voluntary Reporting on Internal Control by Listed Dutch Companies,” MARC Working Paper, 1995, pp. 1-33.

[13] W. Ge and S. McVay, "The Disclosure of Material Weaknesses in Internal Control after the Sarbanes-Oxley Act," Accounting Horizons, Vol. 9, No. 3, 2005, pp. 137158. doi:10.2308/acch.2005.19.3.137

[14] J. F. Cai, "Empirical Research on Internal Control Disclosure of Chinese Listed Companies," Auditing and Economy Research, Vol. 20, No. 2, 2005, pp. 85-88.

[15] S. Bronson, et al., "Firm Characteristics and Voluntary Management Reports on Internal Control,” Auditing: A Journal of Practical and Theory, Vol. 25, No. 2, 2006, pp. 25-39.

[16] X. H. Li, "Empirical Research on Affecting Factors of Internal Control Disclosure,” Zhejiang University Press, Hangzhou, 2007.

[17] H. Ashbaugh-Skaife, D. Collins and W. Kinney, "The Discovery and Reporting of Internal Control Deficiencies Prior to SOX-Mandated Audits," Journal of Accounting and Economics, Vol. 44, 2007, pp. 166-192.

[18] J. Doyle, W. Ge and S. McVay, "The Determinants of Weaknesses in Internal Control over Financial Reporting," New York University, New York, 2007. http://faculty.washington.edu/geweili/DGM_JAE.pdf

[19] M. C. Jensen, “The Modern Industrial Revolution, Exit and the Failure of Internal Control System,” Journal of Finance, Vol. 48, No. 3, 1993, pp. 831-880. doi:10.2307/2329018

[20] S. S. Ho and K. S. Wong, “A Study of the Relationship between Corporate Governance Structure and the Extent of Voluntary Disclosure," Journal of International Accounting: Auditing and Taxation, Vol. 10, No. 2, 2001, pp. 139-156. doi:10.1016/S1061-9518(01)00041-6

[21] L. Eng and Y. T. Mak, "Corporate Governance and Voluntary Disclosure," Journal of Accounting and Public Policy, Vol. 22, No. 4, 2003, pp. 325-345. doi:10.1016/S0278-4254(03)00037-1

[22] W. Z. Xu, "Internal Control Disclosure and Corporate Governance,” Jinan University Press, Guangzhou, 2004.

[23] Z. J. Ma, "Corporate Governance and Internal Control Disclosure of Listed Companies,” Modern Management Science, Vol. 10, 2006, pp. 42-44.

[24] S. Q. Song, "Research on System of Internal Control Disclosure of Chinese Listed Companies,” Huazhong University of Science and Technology, Wuhan, 2008.

[25] S. G. Zhou and L. R. Chen, "Research on the Quality and Affecting Factors of Internal Control Disclosure of Listed Companies: Based on Empirical Evidence from the Perspective of Corporate Governance," Annual Conference Proceedings of Engineering Colleges Branch of China Accounting Association, Vol. 10, 2010.

[26] G. P. Wu, Q. Wang and S. Jia, "Research on the Reliability of Internal Control Information: Empirical Analysis of Annual Reports of Listed Companies in 2006,” Journal of Northeast University (Philosophy and Social Science), Vol. 3, 2008, pp. 50-53.

[27] S. Q. Song and Y. Zhang, "Analysis of the Affecting Factors of Internal Control Disclosure from the Perspective of Corporate Governance," Communication of $\mathrm{Fi}$ nance and Accounting, Vol. 10, 2008, pp. 88-91.

[28] L. R. Chen and S. G. Zhou, "Empirical Research on the Efficiency of Internal Control: Based on the Empirical Evidence from the Perspective of Auditor Changing," Contemporary Finance and Economics, Vol. 10, 2010, pp. 17-21.

[29] Y. F. Yang, H. X. Wang and Q. Cao, "Research on the Correlation between the Quality of Internal Control Information and Agency Costs: Based on the Empirical Research of Companies Listed on Shanghai Stock Exchange in 2007," Auditing Research, Vol. 1, 2010, pp. 82-88. 